\title{
A RECONNAISSANCE OF THE ELEMENT CONTENT OF WAIRARAPA PASTURES AND WHITE CLOVER PLANTS
}

\author{
N. WeLLS \\ Soil Bureau, DSIR, Lower Hutt
}

\begin{abstract}
Summary
Pastures from 35 sites in the Wairarapa have been analysed by rapid techniques for $\mathrm{Ca}, \mathrm{K}, \mathrm{P}, \mathrm{S}, \mathrm{Cl}, \mathrm{Na}, \mathrm{Mg}, \mathrm{Si}, \mathrm{Mn}, \mathrm{Mo}, \mathrm{CU}, \mathrm{Fe}$, $\mathrm{Ti}$, and $\mathrm{Zn}$, in white clover leaves and in mixed pasture species. Four main factors influenced the mean amounts of these elements: they were wind-blown salt $(\mathrm{Na}, \mathrm{Cl})$, soil contamination $(\mathrm{Ti}, \mathrm{Fe}, \mathrm{Si})$, additive effects of applied fertilizer ( $\mathrm{Ca}, \mathrm{K}, \mathrm{P}, \mathrm{S}, \mathrm{MO}$ ), and induced effects of applied fertilizers $(\mathrm{Mg})$. Besides setting the basic requirements for fertilizers, soil factors influenced the uptake of elements as follows: $\mathrm{pH}$ of soil (Mo, Mn), oxidation-reduction state of soil $(\mathrm{Mo}, \mathrm{Mn})$, and depth of soil profile $(\mathrm{Cu}, \mathrm{S})$.
\end{abstract}

\section{INTRODUCTION}

IN order to provide basic information on the chemical composition of. Wairarapa pastures, fourteen elements have been measured in pastures and white clover from a range of soils throughout the Wairarapa district. The measurements involved some 1,000 analyses which were accomplished within a month by the use of modern instrumental techniques. White clover was analysed to compare the availability of elements from the soil to plants as it is more constant in its composition than ryegrass or the mixture of species found in pastures. However, the animals eat a mixture of pasture plants and consequently the analyses of the clover were used as a guide to understanding the factors contributing to the element contents of the pastures.

The plant material was collected in late autumn (May) 1969 and comprised (1) white clover as leaf plus short petiole and (2) mixed pasture species as green matter plucked in short lengths. Thirty-five sites were visited and white clover was obtained from 30 sites; five of the sites were either too dry in summer for white clover maintenance or at a too low level of phosphate nutrition. Dried plant material was analysed by X-ray fluorescence for $\mathrm{Ca}, \mathrm{K}, \mathrm{P}, \mathrm{S}, \mathrm{Cl}, \mathrm{Si}, \mathrm{Mn}$, and $\mathrm{Zn}$, and ashed plant 
TABLE 1: MEAN ELEMENT CONTENTS OF PASTURES AND WHITE CLOVER

\begin{tabular}{|c|c|c|c|c|c|c|c|}
\hline & & & & & $\begin{array}{l}\text { airarapa, } \\
\text { Pasture }\end{array}$ & $\begin{array}{c}\text { Wairarapa, } \\
\text { White Clover }\end{array}$ & $\begin{array}{l}\text { New Z ealand, } \\
\text { White Clover }\end{array}$ \\
\hline \multicolumn{2}{|c|}{ No. of sites } & W. & & ".." & 35 & 30 & 192 \\
\hline $\mathrm{C}$ a $(\%)$ & .1." & & $\ldots$ & $\ldots$ & 0.60 & 1.23 & 1.20 \\
\hline $\mathrm{K} \quad(\%)$ & & 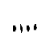 & $\ldots$ & $\ldots$ & 2.0 & 2.5 & 2.5 \\
\hline $\mathrm{P}(\%)$ & $n 11$ & $\ldots$ & & . & 0.29 & 0.34 & 0.35 \\
\hline $\mathrm{s}(\%)$ & $n+1$ & & $\ldots$ & $\ldots$ & 0.28 & 0.28 & 0.32 \\
\hline Cl $(\%)$ & $\ldots$ & $\ldots$ & $\ldots$ & $\ldots$ & 1.4 & 1.4 & 0.5 \\
\hline $\mathrm{N}$ a $(\%)$ & $\ldots$ & $\ldots$ & $\ldots$ & $\ldots$ & 0.35 & 0.28 & 0.10 \\
\hline $\mathrm{Mg}(\%)$ & $\ldots$ & $\ldots$ & $\ldots$ & $\ldots$ & 0.32 & 0.33 & 0.28 \\
\hline $\mathrm{S}$ i $(\%)$ & $\ldots$ & $\ldots$ & $\ldots$ & $\ldots$ & 1.56 & 0.44 & 0.30 \\
\hline Mn (ppm) & . . & $\ldots$ & & $\ldots$ & 390 & 86 & 80 \\
\hline Mo (ppm) . & $\ldots$ & $\ldots$ & $\ldots$ & $\ldots$ & 3.1 & 2.7 & 1.0 \\
\hline $\mathrm{Cu}(\mathrm{ppm})$ & & $\ldots$ & $\ldots$ & & 11.5 & 14.3 & 15.0 \\
\hline $\mathrm{Fe} \quad(\mathrm{ppm})$ & $\ldots$ & $\ldots$ & $\ldots$ & $\ldots$ & 714 & 450 & 100 \\
\hline $\mathrm{Ti} \quad(\mathrm{ppm})$ & & $\ldots$ & $\ldots$ & . . & 177 & 85 & 10 \\
\hline $\mathrm{Zn} \quad(\mathrm{p} p$ & m ) & $\ldots$ & $\ldots$ & $\ldots$ & 45 & 39 & 35 \\
\hline
\end{tabular}

TABLE 2: MAXIMUM R A N G E O F ELEMENT CONTENTS O F PASTURES AND WHITE CLOVER IN WA'IRARAPA

\begin{tabular}{|c|c|c|c|c|c|c|c|}
\hline $\tan =$ & I - & - & $\cdots$ & $\begin{array}{l}\text { Pasture } \\
\text { High }\end{array}$ & $\begin{array}{l}\text { Range } \\
\text { L o W }\end{array}$ & $\begin{array}{l}\text { White Clover } \\
\text { High }\end{array}$ & $\begin{array}{l}\text { Range } \\
\text { L o w }\end{array}$ \\
\hline $\mathrm{C}$ a $(\%)$ & & $\ldots$ & . & 1.07 & 0.25 & 2.04 & 0.24 \\
\hline $\mathrm{K}(\%)$ & & & & 3.75 & 0.60 & 3.65 & 0.50 \\
\hline $\mathrm{P}(\%)$ & $\ldots$ & $\ldots$ & $\ldots$ & 0.48 & 0.14 & 0.47 & 0.19 \\
\hline $\mathrm{s} \quad(\%)$ & $\cdots$ & $\ldots$ & $\ldots$ & 0.50 & 0.16 & 0.59 & 0.17 \\
\hline $\mathrm{Cl}(\%)$ & $\cdots$ & ,.." & $\ldots+1$ & 2.85 & 0.30 & 5.10 & 0.85 \\
\hline $\mathrm{Na}(\%)$ & & & & 0.94 & 0.08 & 0.58 & 0.04 \\
\hline $\operatorname{Mg}(\%)$ & $\ldots$ & $\ldots$ & $\cdots$ & 0.43 & 0.20 & 0.47 & 0.22 \\
\hline $\mathrm{Si}(\%)$ & $\ldots$ & $\ldots$ & $\ldots$ & 3.80 & 0.30 & 1.90 & 0.08 \\
\hline$M n \quad(p p m)$ & 11 & $\ldots$ & $\ldots \prime$ & 1900 & 50 & 350 & 38 \\
\hline M O (ppm) & '1!' & $\ldots$ & .'י! & a. 3 & 0.65 & 15 & 0.36 \\
\hline $\mathbf{C} \mathbf{u}(\mathrm{ppm})$ & $\cdots$ & , & III & 34.2 & 4.1 & 35 & 4.4 \\
\hline F e (ppm) & $\ldots$ & .... & \#! & 1900 & 190 & 1350 & 136 \\
\hline $\mathrm{T}$ i (ppm) & $\ldots$ & $\ldots$ & $\ldots$ & 730 & 14 & 440 & 12 \\
\hline $\mathrm{Zn} \quad(\mathrm{ppm})$ & $\ldots$ & "... & $\ldots$ & 76 & 10 & 69 & 21 \\
\hline
\end{tabular}


material was analysed by emission spectrography for $\mathrm{Na}, \mathrm{Mg}$, Mo, $\mathrm{Cu}, \mathrm{Fe}$, and $\mathrm{Ti}$. The results were expressed on a dry weight b $\begin{array}{lllllll} & \mathrm{a} & \mathrm{s} & \mathrm{i} & \mathrm{s} & & \\ \text {. }\end{array}$

\section{WHITE CLOVER AND PASTURE ANALYSIS}

Table 1 gives the mean values for elements in mixed pasture and in white clover from the Wairarapa, together with the mean values for white clover from 192 sites throughout New Zealand. In the Wairarapa, white clover had more $\mathrm{Ca}, \mathrm{K}, \mathrm{P}$, and $\mathrm{Cu}$ but less $\mathrm{Na}, \mathrm{Si}, \mathrm{Mn}, \mathrm{Mo}, \mathrm{Fe}, \mathrm{Ti}$, and $\mathrm{Zn}$ than the pasture.

The mean values for the composition of white clover (Table 1) show that there were eight similarities and six marked differences in element content between the Wairarapa and the rest of New Zealand. The similarities were for $\mathrm{Ca}, \mathrm{K}, \mathrm{P}, \mathrm{S}, \mathrm{Mg}, \mathrm{Mn}$, $\mathrm{Cu}$, and $\mathrm{Zn}$, while the differences were for $\mathrm{Cl}, \mathrm{Na}, \mathrm{Si}, \mathrm{Mo}, \mathrm{Fe}$, and $\mathrm{Ti}$. The differences were related to three main environmental factors: wind-blown salt, soil contamination, and soil chemistry.

The range of element contents found in pastures and in white clover from the Wairarapa are given in Table 2. In pastures the greatest range of high to low values was for titanium followed by manganese and molybdenum.

The individua! analyses of white clover and pastures and their relation to soils and topdressing have not been tabulated in this paper owing to their large number and the limitations of space. In order to indicate these relationships, however, some reference to this information has been made in the following discussion.

\section{WIND-BLOWN SALT AND SALINITY}

\section{SoDIUM}

The mean value for sodium (and chlorine) in white clover was three times the mean value for New Zealand (Table 1). This related to the strong incidence of wind-blown salt in the Wairarapa. Analysis of sweet vernal (Anthoxanthum odoratum) (Wells, 1962) showed that the sodium levels in this grass in the Wairarapa were mainly in the high to moderate levels with none of the areas mapped in the very low group. Measurements by Blakemore (1953) on rainwaters in the Wairarapa showed that $250 \mathrm{lb} \mathrm{NaCl}$ per acre per annum were deposited in the southern coastal margin, $180 \mathrm{lb}$ at Pirinoa, $40 \mathrm{lb}$ at Martinborough, and $60 \mathrm{lb}$ at Waingawa.

The coastal terraces exposed to salt-bearing winds from the south had white clover with sodium values from 0.4 to $0.5 \%$, 
while plants in the main valley of the Wairarapa (Featherston to Masterton) had 0.2 to $0.3 \%$. However, some of the relatively sheltered inland hill country valleys had 0.1 to $0.2 \% \mathrm{Na}$ in their plants.

Saline soils in southern Wairarapa include soils that occur on land reclaimed by pumping. Although white clover will not grow under conditions of high salinity, the less saline phases had plants with sodium values from 0.5 to $0.6 \% \mathrm{Na}$.

ChLORINE

The element chlorine followed a pattern similar to that of sodium but at a higher level. The chlcrine content of pastures in four regions of the Wairarapa may be summarized as follows:

$\begin{array}{llll}\text { Saline areas } & \ldots & \ldots . & 1.4 \text { to } 5.1 \% \mathrm{Cl} \\ \text { Exposed coastal terraces } & \ldots & 1.5 \text { to } 3.0 \% \mathrm{Cl} \\ \text { Main Wairarapa valley } & \ldots . & 1.0 \text { to } 1.5 \% \mathrm{Cl} \\ \text { Inland hill country } \ldots . . & \ldots & <1.0 \% \mathrm{Cl}\end{array}$

\section{SOIL CONTAMINATION}

The autumn of 1969 was noted for a poor flush of growth which led to hard grazing of pastures. This in turn led to a greater degree of soil contamination of the plants and gave above-average amounts of silicon, iron, and titanium in the white clover (Table 1) and of course in the pasture where the values are extremely high for plant material. Soil on the pasture has been shown by Healy (1967) to be the cause of excessive wear on sheep's teeth and influences the uptake of trace elements by animals.

\section{TitANIUM}

The element titanium is not involved in plant nutrition and occurs at levels below $1 \mathrm{ppm}$ in perfectly clean plant material. Soils, however, contain on average 5,000 ppm Ti. From their titanium content, pastures in the Wairarapa may be classified into three broad groups of soil contamination:

Dirty pastures _ high intensity grazing (e.g., yellow-grey earths)

- thin new swards. $15 \%$ soil

Average pastures — late autumn 1969. 3.5\% soil

Clean pastures — low intensity grazing (e.g., elevated hill -soils)

- lush pastures. $0.3 \%$ soil 


\section{SILICON}

There was a strong positive correlation between silicon and titanium in pastures and in white clover, indicating that soil contamination was the main contributor to the silicon value.

\section{IRON}

There was also a strong positive correlation between iron and titanium in pasture and in white clover but it appeared (from the analyses and the brown coatings on the plants) that, in unusual circumstances of flooding, iron hydroxide could be deposited on the plant unaccompanied by soil,

\section{MAIN FERTILIZER ELEMENTS}

\section{P HOSPHORUS}

No extremely low levels of phosphorus were found in the white clovers from the Wairarapa; this was related to the absence of soils with very high phosphate-fixing capacity (N.Z. Soil Bureau, 1954). The highest rates of topdressing in use (10 cwt superphosphate per acre per annum) had $0.5 \% \mathrm{P}$ in white clover, whereas clover from the non-topdressed sites had $<0.3 \%$ P.

\section{SULPHUR}

The wide use of superphosphate resulted in a strong positive correlation of phosphorus and sulphur in the plants. Under intensive topdressing (10 cwt superphosphate per acre per annum) the white clover had $0.35 \% \mathrm{~S}$. Soils with a strong saline influence due to saline groundwater or wind-blown salt, but with no topdressing, had clover with a similarly high level of sulphur. At the low end of the range of sulphur levels, the steepland soils had a mean value of only $0.23 \% \mathrm{~S}$ in white clover. Pastures on the steepland soils also had very low contents of sulphur.

\section{POTASSIUM}

Very few low potassium values occurred in plants from this Wairarapa survey; it is possible that the poor weather limited plant growth and did not strain the soil resources. High amounts of potassium in white clover were associated with the recent soils from alluvium. 


\section{Calcium}

'The calcium added in superphosphate tended to mask any pattern related to soils. In the sites not receiving topdressing, high calcium levels occurred in plants on steepland soils from limestone and low levels occurred on the saline soils.

\section{MAGNESIUM}

There was a general inverse relationship of the plant magnesium levels to the amount of plant growth induced by topdressing. The very high levels of magnesium $(>0.4 \% \mathrm{Mg})$ in white clover were associated with low levels of phosphorus in the plant. However, a low level of magnesium in white clover was not associated with any particular level of phosphorus. In the saline environment, both groundwaters and wind-blown salt supplied magnesium to the plants.

\section{TRACE ELEMENTS}

\section{MOLYBDENum}

White clover in the Wairarapa averaged $2.7 \mathrm{ppm}$ M compared with $1.0 \mathrm{ppm} \mathrm{Mo}$ for the rest of New Zealand (Table 1). This high mean value was the combination of some naturally high values plus high levels induced by topdressing with molybdic superphosphate.

Very high values occurred in white clover on saline soils (15 ppm Mo) where three factors - high $\mathrm{pH}$, reducing conditions, and absence of anion-retentive clays - combined to make the element available to plants.

The steepland soils and hill soils derived from limestone and calcareous siltstone had above-average pH levels. White clover on these soils (Table 3 ) had high amounts of molybdenum; the steepland and hill soils from non-calcareous sediments - e.g., greywacke - had lower amounts of molybdenum in white clover. Steepland soils, with their young soil profiles, had white clover with higher amounts of molybdenum than the related hill soils.

TABLE 3: MOLYBDENUM IN WHITE CLOVER (ppm )

\begin{tabular}{lllllll}
\hline \multicolumn{2}{c}{ Soils } & \multicolumn{2}{c}{ Limestone } & Parent & Rock & \\
Siltstone & & \multicolumn{2}{c}{ Greywacke } \\
\hline Steepland soils & Mauriceville, & 4.8 & Taihape, & 3.4 & Ruahine, & 1.7 \\
Hill soils & Waimarama, & 2.8 & Atua, & 1.9 & Korokoro, & 1.2 \\
\hline
\end{tabular}


The alluvial deposits gave soils with a wide range of molybdenum in white clover. The very shallow Tauherenikau stony soils had white clover plants with low, amounts of molybdenum $(<0.5 \mathrm{ppm} \mathrm{Mo})$ whereas the soils from fine-textured alluvium and gleyed alluvium (Manawatu sandy loam and Kairanga silt loam) had much higher amounts of molybdenum in white clover (2.5 ppm Mo).

Pastures on sites treated with molybdic superphosphate averaged $4.9 \mathrm{ppm} \mathrm{Mc}$, while pastures on similar soils without molybdenum topdressing averaged. $2.0 \mathrm{ppm}$ Mo.

\section{COPPER}

Studies with sweet vernal from non-topdressed sites (Wells, 1957) showed that steepland soils with thin topsoils gave grass with a low copper content. A similar effect was noted in this investigation of the Wairarapa. The average copper content of white clover from steepland soils (Mauriceville, Mahoenui, Taihape, Ruahine) was $11.1 \mathrm{ppm}$, compared with the mean value of 14.3 for the area. In mixed pasture species on these steepland soils, the mean copper value was $7.3 \mathrm{ppm}$.

Pastures that had been topdressed with copper salts had values as high as $34 \mathrm{ppm} \mathrm{Cu}$ and averaged $23.8 \mathrm{ppm} \mathrm{Cu}$. These values would appear to be excessive.

\section{MANGANESE}

The influence of soil $\mathrm{pH}$ on the level of manganese in plants is opposite to that for molybdenum but for both these elements reducing conditions favour the uptake of the element. A very 'high amount of manganese was found in white clover on a reclaimed saline gley recent soil ( $350 \mathrm{ppm} \mathrm{Mn)}$. Other high values occurred on hill soils from mudstone and greywacke with medium and heavy textures (100 to $150 \mathrm{ppm} \mathrm{Mn)}$ while low values $(<50$ ppm Mn) were found in clover from calcareous steepland soils and from shallow stony soils.

\section{ZINC}

The ranges in zinc values for white clover and pasture were not very great; plants on the recent soils from alluvium had above-average values. 


\section{CONCLUSION}

The results of this analytical reconnaissance showed that the element composition of pastures and white clover in the Wairarapa was controlled by a number of factors. Fertilizers have strongly influenced the mean contents of the main nutrient elements $\mathrm{Ca}, \mathrm{K}, \mathrm{P}$, and $\mathrm{S}$. Wind-blown salt virtually controlled $\mathrm{Na}$ and $\mathrm{Cl}$ levels, and in the exposed areas it also contributed to $\mathrm{Mg}$ and $\mathrm{S}$ levels in pastures. Soil contamination controlled $\mathrm{Ti}, \mathrm{Fe}$ and $\mathrm{Si}$ levels and contributed to a number of trace elements. The soil pattern strongly influenced $\mathrm{Mo}, \mathrm{Mn}, \mathrm{Cu}$ and, to a lesser extent, $\mathrm{S}$.

The Wairarapa has a large area of thin soil profiles in its steepland soils and in its stony soils of the alluvial fans. The limited rooting zone in these shallow soils can result in a nutrient imbalance in pastures. The levels of $\mathrm{Mg}, \mathrm{Cu}$ and $\mathrm{S}$ in plants on these soils are liable to be lowered when the intensity of farming is increased.

\section{ACKNOWLEDGEMENTS}

H, S. Gibbs advised on the selection of sites in the area. J. S. Whitton analysed the samples by emission spectrography and assisted with the analyses by X-ray fluorescence.

\section{REFERENCES}

Blakemore, L. C., 1953: N.Z. Jl Sci. Technol., 35B: 193-7.

Healy, W. B., 1967: Proc. N.Z. Soc. Anim Prod., 27: 109-20.

N.Z. Soil Bureau, 1954: N.Z. Soil Bur. Bull. 5. 286 pp.

Wells, N., 1957: N.Z. Il Sci. Technol., 38B: 884-902.

1962: Single Factor Map No. 59, New Zealand Soil Bureau

Atlas. N.Z. DSIR, Wellington.

\section{JOINT DISCUSSION}

Asked to what extent molybdenum topdressing could cause copper deficiency in animals, Grace could give no definite answer. The amount of uptake of molybdenum in pasture depended on soil type of which there were many. The only sure way of checking was by pasture analyses to give the levels. Wells thought the danger was possibly greater on steep land soils where copper was low. During commented that at Ruakura there was normally molybdenum deficiency at levels less than $1 \mathrm{ppm}$. At more than $1 \mathrm{ppm}$ it was rare to get a response to molybdenum. He thought it unlikely to get toxicity if it were applied where it was deficient, and using only the required amounts. 
Gordon suggested that clovers must be separated from grasses in carrying out analyses. Wells agreed and further stated that the various clover species should also be separated out.

There was no direct evidence of any relationship between copper absorption and selenium. In a trial in the South Island where copper and selenium had been injected, there was a better response in growth and wool weight than from copper alone. The reason was not known. Little work had been done on selenium in pastures. Wells stated that there was a geochemical relationship between selenium and copper. Soils with a high level of copper had a high level of selenium.

The samples for analysis were taken in May. Usually there was a seasonal pattern for molybdenum which normally decreased in summer and increased in winter. The change did not occur if it was wet throughout the year.

It was difficult to find clover of the same genetic background. In future work they would probably use a leaf-marked clover.

Asked the copper level in saline soils, Wells stated that these were usually above average. There did not appear to be a cobalt deficiency, though plants from the stony soils had lower levels than those from other sites, particularly from alluvial soils. 